\title{
Strengthening the Economic Union: the Charter AND THE AGREEMENT ON INTERNAL TRADE
}

\author{
Sujit Choudhry
}

\section{INTRODUCTION}

The standard story in public policy and constitutional circles on the relationship between the Constitution and the Canadian Economic Union is a story of constitutional failure: that the Constitution has proven to be ineffective at furthering the integration of the Canadian economy. ${ }^{1}$ As a consequence, securing this goal requires either constitutional amendment or, in the face of the impossibility of large-scale constitutional change, the use of non-constitutional policy instruments such as the Agreement on Internal Trade, an intergovernmental agreement designed to remove barriers to interprovincial economic mobility. ${ }^{2}$ In this paper, I challenge this view. My argument is that constitutional litigation under the Charter's ${ }^{3}$ mobility rights provisions can serve as an effective alternative to the various mechanisms (adjudication and negotiation) established under the AIT to further the integration of the Canadian economy. Moreover, I suggest how constitutional litigation can actually strengthen the AIT, rather than simply serve as an alternative to it.

The suggestion that the Constitution as it currently stands can help to strengthen the Economic Union will strike most readers as counter-intuitive because the whole impetus to strengthen the Economic Union, whether through constitutional or non-constitutional means such as the $A I T$, assumes the failure of the existing Constitution to achieve that goal. The narrative of constitutional failure has three components.

The clearest statement of this view is found in J. Chrétien, Securing the Canadian Economic Union in the Constitution (Ottawa: Supply and Services Canada, 1980).

2 Canada, Agreement on Internal Trade (Ottawa: Industry Canada, 1994) [hereinafter AIT].

Canadian Charter of Rights and Freedoms, Part I of the Constitution Act, 1982, being Schedule B to the Canada Act 1982 (U.K.), 1982, c. 11 [hereinafter Charter].
The first is the text of the Constitution Act, $1867,{ }^{4}$ which reflects a nineteenth century understanding of barriers to interprovincial economic mobility. Section 121 of the Constitution Act, 1867 appears to only prohibit the imposition of tariffs on goods moving between provinces, ${ }^{5}$ and says nothing about non-tariff barriers. ${ }^{6}$ Nor does it say anything about the mobility of services, capital or labour. Granted, the narrow wording of section 121 need not have been fatal. Section 91(2), the federal trade and commerce power, could have done much of the same work and more with respect to provincially created barriers to economic mobility. Unfortunately, section 91(2) did not live up to its potential because of the second source of constitutional failure - the interpretation given to the Constitution Act, 1867 by the Judicial Committee of the Privy Council. Based on a desire to protect provincial autonomy, the Privy Council adopted a rather expansive interpretation of section 92(13), which confers on the provinces jurisdiction over property and civil rights, and a correspondingly narrow interpretation of section 91(2). Although the case law does not allow the provinces to enact discriminatory barriers to trade ${ }^{8}$ it imposes no discipline whatsoever on provincial policies that inhibit either the inflow of factors of production from other provinces, or the outflow of factors of production to other provinces. The contrast with both the case law under the so-called dormant commerce

Constitution Act, 1867 (U.K.), 30 \& 31 Vict., c. 3, reprinted in R.S.C. 1985, App. II, No. 5 [hereinafter Constitution Act, 1867].

5 Constitution Act, 1867, ibid. at s. 121 provides, "All Articles of the Growth, Produce, or Manufacture of any one of the Provinces shall, from and after the Union, be admitted free into each of the other Provinces."

6 Although some judges have said that it could be interpreted to prohibit measures that are protectionist either on their face, or in intent: see e.g. Murphy v. Canadian Pacific Railway Co., [1958] S.C.R. 626 at 642 (per Rand J.); Reference re Agricultural Products Marketing Act, [1978] 2 S.C.R. 1198 at 1268 (per Laskin C.J.C.).

7 Constitution Act, 1867, supra note 4 at s. 91(2) confers on the federal government jurisdiction over "The Regulation of Trade and Commerce."

8 Manitoba (A.G.) v. Manitoba Egg \& Poultry Assoc., [1971] S.C.R. 689. 
clause $^{9}$ of the American Constitution, as well as the European Court of Justice's case law interpreting the Treaty of Rome, ${ }^{10}$ is striking. ${ }^{11}$

This sense of failure - a sense of thwarted ambition, a sense that the Constitution has been ineffective in creating a Canada that could be more economically integrated, more prosperous and hence better equipped to pursue important national projects put the Economic Union at the centre of the constitutional agenda in both the Patriation and Canada Rounds. ${ }^{12}$ Strengthening the Economic Union, albeit through non-constitutional means, was the focus of many of the recommendations of the MacDonald Commission. ${ }^{13}$ However, both the Patriation package and the Charlottetown Accord contained few of the federal government's initial proposals to strengthen the Economic Union. As a consequence, even if the Charlottetown Accord had been passed, it would have added nothing in the way of new constitutional restraints on the ability of provincial and federal governments to inhibit interprovincial economic mobility. Thus, alongside the inadequacies resulting from the text of the Constitution Act, 1867 and the interpretation thereof, we should add a third: the failure of constitutional amendment.

\footnotetext{
U.S. Const. art. I, $\S 8$.

Treaty establishing the European Economic Community, 25 March 1957, 298 U.N.T.S. 11.

11 The American and European Union jurisprudence, in addition to imposing severe constraints on discriminatory trade barriers, has subjected facially neutral laws that might operate to impede trade flows between trading partners (states, or member states) to probing scrutiny. In the American context see e.g. Hunt $\mathrm{v}$. Washington State Apple Advertising, 452 U.S. 333 (1977). For a recent discussion of the American position see D.H. Regan, "Judicial Review of Member-State Regulation of Trade Within a Federal or Quasi-federal System: Protectionism and Balancing, Da Capo" (2001) 99 U. Mich. L. Rev. 185. In the European context, the first decisions to advance and apply the theory of indirect discrimination arising from regulatory diversity were Procureur du Roi v. Dassonville (No. 8/74), [1974] E.C.R. 837 (goods); Rewe-Zentral AG v. Bundesmonopolverwaltung fur Branntwein (No. 120/78), [1979] E.C.R. 649 [hereinafter Cassis de Dijon] (goods); and Van Bisbergen v. Bestuur van de Bedrijfsverniging voor de Metaalnijverheid (No. 33/74), [1974] E.C.R. 1299 (services). The subsequent case law has modified these cases, and is quite complex. For a good overview, see C. Barnard, "Fitting The Remaining Pieces Into The Goods And Persons Jigsaw" (2001) 26 Eur. L. Rev. 35.

12 For an overview of this history, see M.J. Trebilcock \& R. Behboodi, "The Canadian Agreement on Internal Trade: Retrospects and Prospects" in M.J. Trebilcock \& D. Schwanen, eds., Getting There: An Assessment of the Agreement on Internal Trade (Toronto: C.D. Howe Institute, 1995) 20 at 20-33.

13 Royal Commission on the Economic Union and Development Prospects for Canada, Report of the Royal Commission on the Economic Union and Development Prospects for Canada, vol. 3 (Ottawa: Supply and Services Canada, 1985).
}

In large part, I agree with this story. However, there is a silver lining to this otherwise grim picture, which I think has been largely ignored in the vast literature on the Economic Union. The exception to the narrative of constitutional failure is the entrenchment of section 6 of the Charter in 1982. Section 6 contains a number of mobility rights. Of central importance for our purposes is section 6(2)(b), which enshrines the right of any citizen or permanent resident to pursue the gaining of a livelihood in any province. ${ }^{14}$ Section $6(2)$ (b) has been given a rather expansive interpretation that has taken it far beyond the realm of labour to encompass the mobility of goods. What I want to do next is to outline the evolution of the Supreme Court of Canada's understanding of section $6(2)(b)$, before I contrast constitutional litigation with the mechanisms established under the AIT as alternative means to promote the Economic Union.

\section{MOBILITY RIGHTS AND THE CHARTER}

The best place to start is with the text of section $6(2)(b)$, which guarantees "the right ... to pursue the gaining of a livelihood in any province." In its first Charter case, Skapinker v. Law Society of Upper Canada ${ }^{15}$ the Supreme Court of Canada clarified that section 6(2)(b) was not, despite appearances to the contrary, a right to work unencumbered by regulations, such as professional licensing requirements. Rather, as La Forest J. explained in a later decision, Black v. Law Society of Alberta,${ }^{16}$ section 6(2)(b) enshrines a right to gain a livelihood in a province on terms that do not discriminate on the basis of residency, either between residents and non-residents of that province, or among residents on the basis of length of residence. Although the Court did not refer to the international trade literature, the idea of non-discrimination is clearly equivalent to the principle of national treatment, a hallmark of negative integration. By negative integration I mean the elimination of discriminatory treatment of out-of-jurisdiction factors of production. And Black added another element to section 6(2)(b) namely, that there be some kind of interprovincial aspect to the gaining of a livelihood, the so-called mobility element of section 6(2)(b). The central idea here is that a citizen or permanent resident should be

\footnotetext{
14 Charter, supra note 3, s. 6(2)(b) states, "Every citizen of Canada and every person who has the status of a permanent resident of Canada has the right ... (b) to pursue the gaining of a livelihood in any province."

15 Skapinker v. Law Society of Upper Canada, [1984] 1 S.C.R. 357 [hereinafter Skapinker].

16 Black v. Law Society of Alberta, [1989] 1 S.C.R.591 [hereinafter Black].
} 
able to earn a livelihood without regard to provincial borders, that is, as if those borders did not exist.

As with any constitutional provision, there are easy cases and hard cases for section 6(2)(b). In the central case, an individual would shift her province of residence in search of better employment prospects, and what section $6(2)$ (b) would protect would be her right to be treated equally under the law of her new province of residence with respect to her ability to gain a livelihood. For example, section 6(2)(b) presumptively prohibits governments from discriminating in employment on the basis of length of residence, which is tantamount to prohibiting discrimination on the basis of province of prior residence. Another example of an easy case, which was provided by the Court in Skapinker, is that of a trans-border commuter, living in one province but working in another, who faces restrictions on her ability to work solely because she does not reside in her province of employment. There, the discrimination would be on the basis of province of present residence. In both of these cases, physical movement between provinces in connection with employment would satisfy the mobility element. The implicit image here is one of workers (i.e. wage labour) spreading out over the vast Canadian expanse, in search of economic opportunity.

But there are harder cases as well. Consider Black. The background to Black was the decision by McCarthy \& McCarthy, now McCarthy Tétrault, to become Canada's first national law firm with offices from coast to coast. McCarthy \& McCarthy wanted to open an office in Calgary. Fearful of out-of-province competition, the Law Society of Alberta responded by enacting a series of by-laws designed to discourage outof-province firms from establishing offices in Alberta (and competing with Alberta-based firms). Two of these by-laws ended up before the Supreme Court. One of the by-laws (R154) prohibited resident members of the Alberta bar from entering into partnerships with non-resident members. The other by-law (R75B) prohibited members of the Alberta bar from being partners in more than one firm.

To be sure, in some ways Black was an easy case. The first of these by-laws openly discriminated between resident and non-resident members of the Alberta bar; the former were able to form partnerships with resident members, whereas the latter were not. This was clearly a facially discriminatory distinction on the basis of residence. Moreover, the by-law disadvantaged nonresidents in their ability to gain a livelihood in Alberta because partnerships are the most common way of practicing law, and the inability of non-residents to enter into partnerships with residents put them at an economic disadvantage.

But there were other aspects of Black that were more difficult. First, there was the mobility element itself. The challenge to the by-laws was brought by members of the Alberta Bar who were resident in Ontario, not in Alberta. Most of these lawyers made very infrequent trips to Alberta, and, in fact, probably offered legal advice to Alberta clients on matters of Alberta law out of their Toronto offices. These were not trans-border commuters who physically crossed provincial boundaries to work every day, but they nonetheless did participate in the economic life of a province other than their province of residence. Faced with these facts, the Court responded by loosening up the mobility requirement, stating that it would be met if an individual pursued a living in a province, even without being physically present there. In a later case, Canadian Egg Marketing Agency v. Richardson, ${ }^{17}$ the Court affirmed this position, stating that in light of modern technology, what really counts is whether someone is attempting to create wealth in another province. This is a decidedly twentieth century conception of economic mobility. To be sure, the Charter is a twentieth century constitutional document, but Black nonetheless had to contend with paradigmatic, if somewhat dated examples of interprovincial mobility centred on physical movement.

Another difficult point in Black was the rule against partnership in more than one firm. The rule applied equally to all members of the Alberta bar, both resident and non-resident, and accordingly would appear to not discriminate on the basis of residence. However, the Court reasoned that although the rule was facially neutral, it had a disparate impact on nonresidents, and therefore indirectly discriminated against them. The reason why the law disproportionately burdened non-residents was that very few residents would have the need to enter into more than one partnership, whereas for non-residents, the ability to enter into multiple partnerships - one in Alberta, one in their province of residence - would be essential to being able to practice in Alberta.

17 Canadian Egg Marketing Agency v. Richardson, [1998] 3 S.C.R. 157 [hereinafter Richardson]. Note: I disclose that I served as law clerk to Chief Justice Antonio Lamer during the 1996-97 term, when Canadian Egg Marketing Agency v. Richardson was heard. Nothing in this paper reveals any confidential information acquired during that time. 
Faced with these breaches of section $6(2)(b)$, the Court then turned to section $6(3)(a) .{ }^{18}$ As drafted, section 6(3)(a) looks like a savings clause, and allows for the limitation of mobility rights by laws of general application other than those that discriminate primarily on the basis of province of present or prior residence. The Court held that both by-laws could not be upheld under section $6(3)$ (a) because they were both discriminatory. ${ }^{19}$ This way of approaching justifiable limits created a bit of a problem. The problem was that laws that contravened section 6(2)(b) would fail the test of justification for the very same reason that they contravened section $6(2)(\mathrm{b})$, i.e. because they were discriminatory. To be fair, that was not the end of the matter; all Charter rights, including mobility rights, are subject to a general limitation clause, section $1 .^{20}$ To defenders of Charter mobility rights, section 1 serves as a safety valve, allowing governments to justify mobility-restricting measures. To critics of mobility rights, the need to resort to section 1 is extremely dangerous. The reason for concern is that the simple existence of regulatory diversity between provinces can itself give rise to claims of indirect discrimination. To these critics, Black meant that all manner of provincial public policies that create indirect barriers to economic mobility would be subject to constitutional justification under section 1, putting courts in the position of second-guessing provincial public policy.

To be sure, this is not a concern confined to mobility rights cases, and arises whenever government policies are found to contravene Charter rights. However, given that section 6(2)(b) is an economic right, and that Black implies that simple regulatory diversity contravenes that provision, section $6(2)(\mathrm{b})$ would subject a far broader range of socio-economic policies to section 1 analysis than would violations of other Charter rights. In this connection, it is worth noting that opponents of the Economic Union aspect of the federal government's proposals in the Canada Round feared that those amendments would launch a Canadian version of the Lochner era, a period of

18 Charter, supra note 3 at s. 6(3)(a) states, "The rights specified in subsection (2) are subject to (a) any laws and practices of general application in force in a province other than those that discriminate among persons primarily on the basis of province of present or previous residence."

19 It is worth noting, though, that the Court shifted its analysis regarding $\mathrm{R} 75 \mathrm{~B}$, suggesting that although facially neutral, it was discriminatory, not simply because of its unequal impact on non-residents but because it had been enacted for a colourable motive, i.e. for the purpose of putting non-residents at a competitive disadvantage, at para. 74 .

20 Charter, supra note 3 at s. 1 states, "The Canadian Charter of Rights and Freedoms guarantees the rights and freedoms set out in it subject only to such reasonable limits prescribed by law as can be demonstrably justified in a free and democratic society."
American constitutional history in which the U.S. Supreme Court struck down all manner of socioeconomic legislation in furtherance of what we would now call a neo-liberal economic agenda. ${ }^{21}$ Given that the drafting history of the Charter evinces a clear intention to avoid the libertarian legacy of Lochner, ${ }^{22}$ Black set off alarm bells.

These concerns were raised and addressed by Richardson, a case that at once expanded and contracted the scope of section 6(2)(b). Richardson involved a challenge to the national egg-marketing scheme, centred on the Canadian Egg Marketing Agency. Under the scheme, global production limits are set for each province, and within each province federal and provincial egg marketing boards allocate that global limit to individual producers in the form of production quotas. Only producers with quotas are entitled to market eggs interprovincially. The feature of the scheme that gave rise to the constitutional challenge is that no quota was allocated to producers in the Northwest Territories (NWT), because it was not a party to the scheme. The NWT was not a party because when the scheme was set up in 1972 there was no egg production in the NWT. At the time of the appeal, production quotas were allocated on the basis of historical levels of production. To an important extent then, the exclusion of the NWT can be regarded as a historical accident. Two parties, Richardson and Pineview Poultry, who owned and operated chicken farms in the NWT and who wished to market their eggs interprovincially, brought the constitutional challenge.

The claim in Richardson pushed the limits of section 6(2)(b) for three reasons. First, the claim seemed to have little to do with labour mobility rights. In Richardson, the only things moving across provincial borders were eggs, and even the most ardent Charterphile would not assert that eggs possess constitutional rights. As a consequence, government lawyers strenuously argued that the plaintiffs were attempting, through the vehicle of section 6(2)(b), a provision that grants rights to people, to craft a right to interprovincial trade in goods - an internal free trade provision that our Constitution currently lacks, a sort of revised section 121 . Second, the previous mobility rights cases (Skapinker, Black) involved claims brought by natural persons. But one of the plaintiffs in this case was a corporation, an artificial legal person. In most areas of

21 For a good discussion see D. Schneiderman, "The Constitutional Politics of Poverty" in J. Bakan \& D. Schneiderman, eds., Social Justice and the Constitution: Perspectives on a Social Union for Canada (Ottawa: Carleton University Press, 1992) 125.

22 See S. Choudhry, "The Lochner Era and Comparative Constitutionalism" [unpublished manuscript]. 
law nothing really turns on this difference because artificial legal persons have many, if not most of the rights that natural legal persons do. But the Charter is fundamentally different because it is a human rights document whose raison d'etre is the protection of the interests of human beings. It was thus argued that corporations should not be able to invoke the mobility rights provision out of a concern that corporations were attempting to convert section $6(2)(\mathrm{b})$ into a new and improved section 121. Third, the egg-marketing scheme seemed to distinguish among egg producers not on the basis of province of residence, but province of production. This distinction, it was argued, mattered a great deal in the particular case because Richardson was a resident of Alberta, although his business was located in the NWT. Accordingly, since he was a resident of a province in which quota was available, it was argued that he was not discriminated against on the basis of province of residence.

Richardson is a very important decision because notwithstanding these challenges, the Court sided with the plaintiffs on all three of these points. It held that producing and shipping goods was just another way of gaining a livelihood, which stood alongside selling one's labour or providing services, and hence that interprovincial economic activity of any kind is protected by the Charter. Presumably, the next step will be to seek to protect capital mobility under the Charter by challenging the constitutionality, for example, of provincial laws that limit land ownership by nonresidents. ${ }^{23}$ On the issue of corporations and the Charter, the Court sidestepped the difficult questions raised by the case, and held that the claimants had standing to challenge the constitutionality of the eggmarketing scheme, because they launched the challenge in defence of an application by the Canadian Egg Marketing Agency for a civil injunction against its attempt to market goods interprovincially. ${ }^{24}$ This amounted to an extension of the pre-existing case law, which had permitted corporations defending against criminal proceedings to raise Charter arguments that they could not assert as of right. ${ }^{25}$ Finally, with respect to residency, the Court simply stated that "it would be an egregious formalism" ${ }^{26}$ to force apart residency and production, presumably because the two are most often

23 Interestingly, though, Prince Edward Island's restrictions on land ownership by non-residents have withstood constitutional challenge under s. 6(2)(b). See McCarten v. Prince Edward Island (1994), 112 D.L.R. (4 $\left.{ }^{\text {th }}\right) 711$ (P.E.I. S.C. (A.D.)).

24 Canada (Egg Marketing Agency) v. Richardson (1995), 129 D.L.R. $\left(4^{\text {th }}\right) 195$ (N.W.T. S.C.).

25 This is the so-called Big $M$ exception, so termed because it was first applied in R. v. Big M Drug Mart Ltd., [1985] 1 S.C.R. 295.

26 Richardson, supra note 17 at para. 97. closely intertwined. Taken together, the various holdings in Richardson show us how far we have traveled from the personal mobility right for wage labour that section 6(2)(b) was originally conceived as being limited to. The Court was really on the verge of converting that provision into a revised section 121 .

However, perhaps precisely because it was staring this prospect in the face, the Court in Richardson did take this final step by making it much easier for governments to justify limits on mobility rights than had previously been the case. Reinterpreting the relationship between sections 6(2)(b) and 6(3)(a), the Court determined that only laws that primarily discriminated on the basis of present or prior province of residence would violate section 6(2)(b). What does this mean? It means that unless the dominant purpose or effect of the challenged public policy is discriminatory - be the policy facially neutral or facially discriminatory - there is no violation of the Charter. In Richardson, for example, a majority of the Court held that the motives behind the use of the historical production patterns system were entirely valid because the system was "an equitable means of distributing quotas for the orderly and fair marketing of commodities," ${ }^{27}$ and that in terms of discriminatory effects, the claimants had not proved that they were any worse off than producers in the ten participating provinces but who lacked quota and were therefore precluded from marketing eggs interprovincially as well. The dissent disagreed on both counts. First, it correctly noted that the exclusion of the NWT arose largely as a result of historical accident, not a reasoned decision as to what was the most equitable way to regulate the marketing of eggs, and suggested that the on-going exclusion of the NWT was "in the interests of the provincial producers and exporters who control the scheme" centred on the Canadian Egg Marketing Agency. ${ }^{28}$ Second, the dissent also noted that producers in the NWT were definitely worse off than those in provinces without quota, because they were legally precluded from obtaining quota at all.

In conclusion, the picture under section $6(2)(\mathrm{b})$ is mixed, with the Court adopting an expansive interpretation of the provision, while at the same time contracting it. In the next section, I compare and contrast section 6(2)(b) and the AIT to discuss which is more effective in securing the Economic Union. My focus will be on those provisions of the AIT that further the project of negative integration, because these could potentially serve as partial functional substitutes for constitutional litigation under section 6(2)(b).

\footnotetext{
Ibid. at para. 96

28 Ibid. at para. 118.
} 


\section{CHARTER MOBILITY RIGHTS VS. THE AIT}

The $A I T$ is an intergovernmental agreement entered into by the federal government and all ten provinces in 1994 and which came into force in 1995. The AIT has as its goal the elimination of barriers to economic mobility within Canada. ${ }^{29}$ Although motivated by economic considerations - i.e. the economic benefits that would result from increased interprovincial economic activity - the AIT, along with the Social Union Framework Agreement, ${ }^{30}$ should be seen as an attempt to renew the federation through nonconstitutional means. The $A I T$ is comprehensive in scope, covering the mobility of goods, services, capital and persons in all areas of economic activity, although there are sectoral chapters dealing with government procurement, investment, etc. The AIT is modeled on international trade agreements in two respects. First, its primary focus is negative integration. However, the AIT also creates the framework for intergovernmental negotiations to eliminate barriers to mobility arising from interprovincial regulatory diversity (known as positive integration). ${ }^{31}$ The sense among commentators is that the positive integration agenda of the $A I T$ has not been particularly successful. ${ }^{32}$ Second, the $A I T$ contains a dispute settlement machinery to deal with alleged violations of the $A I T$. In the wake of the $C A P$ Reference, ${ }^{33}$ it is widely accepted that neither the AIT nor the decisions of $A I T$ panels are justiciable in the ordinary courts, ${ }^{34}$ and that the AIT does not operate to fetter legislative sovereignty.

So how do the AIT and section 6(2)(b) compare? If we compare the $A I T$ and section $6(2)(\mathrm{b})$ as instruments of negative integration, there are two significant

29 D. Schwanen, "Canadian Regardless of Origin: 'Negative Integration' and the Agreement on Internal Trade" in H. Lazar, ed., Non-Constitutional Renewal (Kingston: Institute of Intergovernmental Relations, 1998) 169.

30 A Framework to Improve the Social Union for Canadians - An Agreement between the Government of Canada and the Governments of the Provinces and Territories (4 February 1999).

31 For a discussion and comparison of negative and positive integration, see Trebilcock \& Behboodi, supra note 12 at 33-39.

32 See e.g. D. Schwanen, "Happy Birthday, AIT!" (2000) 21:6 Policy Options 51 .

33 Reference re Canada Assistance Plan (B.C.), [1991] 2 S.C.R. 525 [hereinafter CAP Reference].

${ }^{34}$ With the exception of non-discrimination in procurement by the federal government, which falls within the jurisdiction of the Canadian International Trade Tribunal (CITT) pursuant to $\mathrm{s}$. $3(1)$ of the Canadian International Trade Tribunal Procurement Inquiry Regulations, S.O.R./93-602. Decisions of the CITT are subject to judicial review by the Federal Court of Canada. respects in which section $6(2)(\mathrm{b})$ is more effective. First, section $6(2)(b)$ is a constitutional provision, which binds both the legislative and executive branches of government. Indeed, it is not subject to the legislative override created by section 33 of the Charter. The AIT, by contrast, is an intergovernmental agreement which is legally unenforceable. In light of the CAP Reference, and the express language of Article $300,{ }^{35}$ the $A I T$ does not operate to fetter legislative sovereignty. Moreover, even though one reading of the CAP Reference keeps this possibility open, ${ }^{36}$ Article 300 makes it clear that the AIT does not bind either the federal or provincial executives. Because of the nonlegal character of the AIT its effectiveness will always depend on the willingness of governments to comply with it. Governments will always be free to ignore an inconvenient ruling, or to refuse to cooperate with the dispute settlement procedure, paying at most a political price for non-performance. Second, under Article 101(3)(a), the AIT only applies to new barriers to internal trade created after the coming-into-force of the agreement on 1 July 1995. ${ }^{37}$ This leaves existing barriers beyond the reach of the complaints procedure, and, ultimately, beyond adjudication. This severely limits the effectiveness of the AIT. By comparison, no such limitation applies to the Charter. In Richardson, for example, the relevant system was created in the 1970 s.

But when we turn to the substantive principles of negative integration, neither the AIT nor section 6(2)(b) seems to enjoy a clear advantage over the other. First, the AIT applies to the mobility of all factors of production - i.e. goods, service, capital and labour. It is fair to say that when section 6(2)(b) was enacted, it was viewed as being limited in scope to labour mobility, and as having no direct relevance to the mobility of other factors of production. Moreover, section 6(2)(b) was understood as a right exercisable by natural legal persons. Now, through judicial interpretation, those initial expectations have been displaced. Not only persons, but also goods and

35 Article 300 of the AIT, supra note 2 states, "Nothing in this Agreement alters the legislative or other authority of Parliament or of the provincial legislatures or of the Government of Canada or of the provincial governments or the rights of any of them with respect to the exercise of their legislative or other authorities under the Constitution of Canada."

36 S. Choudhry, "The Enforcement of the Canada Health Act" (1996) 41 McGill L.J. 461 at 504.

37 Article 101(3)(a) of the AIT, supra note 2 states, "In the application of this Agreement, the Parties shall be guided by the following principles: ... Parties will not establish new barriers to internal trade and will facilitate the cross-boundary movement of persons, goods, service and investments within Canada." Under Article 1814, the AIT came into force on 1 July 1995. 
services, and likely capital as well, are covered by the provision. Moreover, corporations can now take advantage of section $6(2)(b)$, at least in some circumstances ${ }^{38}$ Second, if we compare section 6(2)(b) and Article $401,{ }^{39}$ both proscribe facially discriminatory measures. Moreover, section 6(2)(b) and Article 402 proscribe measures that are neutral on their face, but which have been enacted for a protectionist or colourable purpose; an example of the latter sort of barrier to trade was the provincial regulation at issue in the PEI Dairy case. ${ }^{41}$ Third, Richardson affirmed that section 6(2)(b) still regulates indirect discrimination arising from regulatory diversity; the $A I T$, at least on the face of Article 402, might as well. However, to be fair, the relative youth of the AIT means that this important question remains unanswered. Moreover, the Court's comments in Richardson suggest that it will be

See the discussion, supra note 23 and accompanying text.

Article 401 of the AIT, supra note 2, states in full:

1. Subject to Article 404, each Party shall accord to goods of any other Party treatment no less favourable than the best treatment it accords to:

(a) its own like, directly competitive or substitutable goods; and

(b) like, directly competitive or substitutable goods of any other Party or non-Party.

2. Subject to Article 404, each Party shall accord to persons, services and investments of any other Party treatment no less favourable than the best treatment it accords, in like circumstances, to:

(a) its own persons, services and investments; and

(b) persons, services and investments of any other Party or non-Party.

3. With respect to the Federal Government, paragraphs 1 and 2 mean that, subject to Article 404, it shall accord to:

(a) the goods of a Province treatment no less favourable than the best treatment it accords to like, directly competitive or substitutable goods of any other Province or non-Party; and

(b) the persons, services and investments of a Province treatment no less favourable than the best treatment it accords, in like circumstances, to persons, services and investments of any other Province or non-Party.

4. The Parties agree that according identical treatment may not necessarily result in compliance with paragraph 1,2 or 3 .

40 Article 402, supra note 2, states, "Subject to Article 404, no Party shall adopt or maintain any measure that restricts or prevents the movement of persons, goods, services or investments across provincial boundaries."

41 Re Amendments to Dairy Industry Act Regulations, File No. 98/99 (18 January 2000). One of the issues in this complaint was the compliance with the AIT of a provincial regulation that governed the granting of licences of dairy processors and distributors in P.E.I. Although the regulation was facially neutral, the dispute settlement panel found that the purpose behind the regulation was to protect local milk producers from out-of-province competition, and for that reason the regulation contravened Article 402. Oddly enough, the panel did not attempt to uphold the regulation under Article 404, notwithstanding the express terms of Article 402, perhaps because the regulation had not been enacted for "a legitimate objective." very reluctant to find that indirect discrimination arising from regulatory diversity per se breaches section $6(2)(b)$, for such a holding, in its view, would allow the Charter to undo what the Court sees as another basic objective of the Constitution: to allow provincial communities to make their own choices as to the public policies they will live by, an objective which is bound to create regulatory diversity.

By comparison, with respect to limitation analysis, the AIT clearly comes out ahead. Under Article 404, ${ }^{42}$ a trade-limiting measure must meet a multi-part test, as explained by the panel in the $M M T$ case: $:^{43}$ the measure must pursue a legitimate objective, it must not unduly impair the access of factors of production, it must be no more trade restrictive than necessary to achieve the legitimate objective, and it must not be a disguised restriction on trade. I would actually collapse these into a two-part test: that the measure be motivated by legitimate, and not protectionist reasons, and that the measure minimally impair trade. Framed in these terms, Article 404 sounds a great deal like the Oakes test under the Charter's limitation clause, section $1 .{ }^{44}$ What Richardson has done, though, is to prevent the courts from addressing the issue of minimal impairment. However, I very much doubt that Richardson is the last word on this subject. It is worth noting, in particular, that the current Chief Justice was in dissent in that case.

\section{CONCLUSION: HOW CONSTITUTIONAL LITIGATION CAN MAKE THE AIT MORE EFFECTIVE}

Thus far I have been viewing the mechanisms centred on the AIT and constitutional litigation as alternatives to furthering the Canadian Economic Union. By way of conclusion, I want to suggest one way in which constitutional litigation can make the $A I T$

\footnotetext{
42 Article 404 of the AIT, supra note 2, states in full: Where it is established that a measure is inconsistent with Article 401, 402 or 403, that measure is still permissible under this Agreement where it can be demonstrated that:

(a) the purpose of the measure is to achieve a legitimate objective;

(b) the measure does not operate to impair unduly the access of persons, goods, services or investments of a Party that meet that legitimate objective;

(c) the measure is not more trade restrictive than necessary to achieve that legitimate objective; and

(d) the measure does not create a disguised restriction on trade.

43 Re Manganese-Based Fuel Additives Act, File No. 97/99 (12 June 1998).

${ }^{44}$ R. v. Oakes, [1986] 1 S.C.R. 103.
} 
more effective. The key here is to build upon an important insight in Black: that the simple existence of regulatory diversity can give rise to a constitutional challenge under section 6(2)(b). Although Richardson has tried to shut down this line of argument, as I suggested earlier the logic of Black could resurface again.

Why would this doctrinal move with respect to the interpretation of section 6(2)(b) make the AIT more effective? The difficulty with litigating indirect discrimination, as the European case of Cassis de Dijon $^{45}$ indicates, is that it creates the danger that the province with the lowest standards will set the norm for the federation as a whole, through a series of trade challenges launched by economic entities resident in that province against the laws of other provinces. As Robert Howse has suggested, the prospect of a litigated race to the bottom might provide an extremely strong incentive to the provinces and federal government to further the project of positive integration, through the negotiation of mutual recognition and/or harmonization. ${ }^{46}$ And this kind of litigation strategy would have the additional attraction of relying on an appropriate institutional division of labour between courts and political institutions, with the former undertaking the task of negative integration, but the latter having the final say on the substance of the public policies.

If I am right, then those entities which have an interest in ensuring the success of the AIT would ironically help it most if they shifted their attention to the courts. And in this connection, it is worth noting that those economic interests most committed to promoting economic mobility have not intervened in Supreme Court cases in which section 6(2)(b) has been at issue. Perhaps this should change. $\square$

\section{Sujit Choudhry}

Faculty of Law, University of Toronto.

An earlier version of this paper was presented at "Strengthening Canada: Challenges for Internal Trade and Mobility" June 2001, Colony Hotel,
Toronto, Ontario, and appears in the proceedings to that conference under the title "The Agreement on Internal Trade, Economic Mobility, and the Charter." I thank Tsvi Kahana and Ira Parghi for helpful comments.

45 Supra note 11. This case involved a challenge to a German product standard (minimum alcohol content for fruit liqueur). Although the rule was not facially discriminatory, it had the effect of impeding access to the German market for similar products from other jurisdictions with a lower alcohol content. The judgment established the rule that simple interjurisdictional regulatory diversity would amount to a trade barrier, and would be illegal unless the trade-restricting rule met a test of justification.

46 R. Howse, Securing the Canadian Economic Union: Legal and Constitutional Options for the Federal Government (Toronto: C.D. Howe Institute, 1996). 